\title{
Efforts to Improve The Understanding of Mathematics Concepts of Two- Dimentional Figures Materials Using Powerpoint Media in Primary Schools
}

\section{Indah Cahyani}

SD Negeri Kalisari

indahmendowan@gmail.com

\section{Article History}

accepted 14/11/2020

approved 21/11/2020

published 26/11/2020

\begin{abstract}
This article is intended to understand the mathematical concept of the two-dimentional figure data for the second grade students of elementary schools of Kalisari for the year of Caliology in 2020/2021. This study uses two cycles. Each cycle begins with planning, execution, observation, and reflection. The results of the study in first cycle showed $62 \%$ complete education and in second cycle an increase of first cycle, 81\% students has complete among 21 education participants in the second cycle. The results showed that the PowerPoint media improved the understanding of the concept of students in Elementary School of Kalisari second grade level intangible architectural mathematical ability.
\end{abstract}

Keywords: two-dimentional figure, powerpoint, second grade

\begin{abstract}
Abstrak
Artikel ini menjelaskan tentang pemahaman konsep matematika materi bangun datar dengan media powerpoint untuk peserta didik kelas II SD Negeri Kalisari tahun pembelajaran 2020/2021. Penelitian ini menggunakan dua siklus. Dimana setiap siklusnya dimulai dengan perencanaan, pelaksanaan, observasi, dan refleksi. Hasil dari penelitian ini adalah pada siklus 1 terlihat hasil berikut, $62 \%$ peserta didik tuntas dan pada siklus 2 terlihat peningkatan dari siklus $1,81 \%$ peserta didik tuntas dari 21 peserta didik. Hasil iini menunjukkan bahwa media powerpoint meningkatkan pemahaman konsep peserta didik dalam kemampuan matematika materi bangun datar pada kelas II SD Negeri Kalisari.
\end{abstract}

Kata kunci: bangun datar, powerpoint, Kelas II

Social, Humanities, and Education Studies (SHEs): Conference Series https://jurnal.uns.ac.id/shes

p-ISSN 2620-9284

e-ISSN 2620-9292 


\section{PENDAHULUAN}

Pendidikan adalah usaha sadar dan terencana untuk mewujudkan suasana belajar dan proses pembelajaran agar peserta didik secara aktif mengembangkan potensi dirinya untuk memiliki kekuatan spiritual keagamaan, pengendalian diri, kepribadian, kecerdasan, akhlak mulia, serta keterampilan yang diperlukan dirinya, masyarakat, bangsa, dan negara (Undang-Undang No. 20 tahun 2003).

Pendidikan pada hakekatnya merupakan suatu upaya mewariskan nilai, yang akan menjadi penolong dan penentu umat manusia dalam menjalani kehidupan sekaligus memperbaiki nasib dan peradaban umat manusia. Tanpa pendidikan, diyakini bahwa manusia sekarang tidak jauh berbeda dengan generasi manusia masa lampau, yang dibandingkan dengan manusia sekarang, telah sangat tertinggal baik kualitas kehidupan maupun proses-proses pemberdayaannya. Secara ekstrim bahkan dapat dikatakan bahwa maju mundurnya atau baik buruknya peradaban suatu masyarakat, suatu bangsa, akan ditentukan oleh bagaimana pendidikan yang dijalani oleh masyarakat bangsa tersebut.

Sebagai bagian dari kebudayaan, pendidikan sebenarnya lebih memusatkan diri pada proses belajar mengajar untuk membantu anak didik menggali, menemukan, mempelajari, mengetahui, dan menghayati nilai-nilai yang berguna, baik bagi diri sendiri, masyarakat, dan negara sebagai keseluruhan (Sudarwan, 1995:3). Selain itu pendidikan mempunyai peranan penting dalam mengembangkan sumber daya manusia, supaya anak didik menjadi manusia yang berkualitas, profesional, terampil, kreatif, dan inovatif. Pemerintah Republik Indonesia telah bertekad memberikan kesempatan kepada seluruh warga negara Indonesia untuk menikmati pendidikan yang bermutu, sebagai langkah utama meningkatkan taraf hidup warga negara sebagai agen pembaharu, pendidikan bertanggung jawab dalam mengembangkan dan mewariskan nilai untuk dinikmati anak didik yang selanjutnya nilai tersebut akan ditransfer dalam kehidupan sehari-hari.

Berdasarkan pengamatan peneliti pada waktu observasi, kenyataan di lapangan khususnya pada pembelajaran Matematika materi bangun datar di kelas II SD Negeri Kalisari Cilongok kurang optimal dalam memanfaatkan maupun memberdayakan sumber belajar, karena pembelajaran Matematika di kelas II tersebut cenderung masih konvensional, pembelajaran masih berpusat pada guru (teacher centered), text book, dan sedikit media. Guru hanya menggunakan media konvensional yaitu berupa papan tulis, kapur, buku pegangan siswa, dan LKS. Guru masih mendominasi proses pembelajaran sedangkan siswa masih nampak pasif. Guru lebih banyak menggunakan metode ceramah dalam setiap penyampaian materi pelajaran Matematika , karena menurut guru metode ceramah merupakan metode yang paling mudah dilaksanakan oleh setiap guru. Hal ini menyebabkan banyak siswa di kelas II SD Negeri Kalisari menganggap proses pembelajaran Matematikaa adalah sesuatu yang membosankan, monoton, kurang menyenangkan, terlalu banyak hafalan, kurang variatif, dan berbagai keluhan lainnya.

\section{PENELITIAN TINDAKAN KELAS}

a. Pengertian Penelitian Tindakan Kelas

Penelitian tindakan kelas adalah penelitian yang dilakukan oleh guru di dalam kelasnya sendiri melalui refleksi diri, dengan tujuan untuk memperbaiki kinerjanya sebagai guru, sehingga hasil belajar siswa menjadi meningkat.

b. Langkah-langkah Penelitian Tindakan Kelas

\section{PEMAHAMAN KONSEP}

Pemahaman diartikan sebagai proses, perbuatan, cara memahami atau memahamkan (Kamus Besar Bahasa Indonesia, 1989: 13). Pemahaman merupakan terjemahan dari istilah understanding yang diartikan sebagai penyerapan arti suatu materi yang dipelajari (Herdian, 2010). Menurut Sardiman (dalam Andi, 2012) 
menyatakan bahwa pemahaman atau comprehension dapat diartikan menguasai sesuatu dengan pikiran.

Nasoetion (Sri Subarinah, 2006: 1) mengemukakan bahwa istilah "Matematika" berasal dari kata Yunani mathein atau manthenin yang artinya "mempelajari". Mungkin juga kata itu erat hubungannya dengan kata sansekerta medha atau widya yang artinya ialah "kepandaian", "ketahuan" atau "intelegensi". Dengan menguasai matematika, orang akan belajar mengatur jalan pemikirannya dan sekaligus belajar menambah kepandaiannya.

Bangun datar adalah bangun dua demensi yang hanya memiliki panjang dan lebar, yang dibatasi oleh garis lurus atau lengkung. Bangun-bangun geometri baik dalam kelompok bangun datar maupun bangun ruang merupakan sebuah konsep abstrak. Artinya bangun-bangun tersebut bukan merupakan sebuah benda konkret yang dapat dilihat maupun dipegang. Demikian pula dengan konsep bangun geometri, bangun-bangun tersebut merupakan suatu sifat, sedangkan yang konkret, yang biasa dilihat maupun dipegang, adalah benda-benda yang memiliki sifat bangun geometri. Misalnya persegi panjang, konsep persegi panjang merupakan sebuah konsep abstrak yang diidentifikasikan melalui sebuah karakteristik.

Azhar Arsyad (2003: 3) menjelaskan bahwa kata media berasal dari bahasa latin medius yang secara harfiah berarti "tengah" "perantara" atau "pengantar". Dalam bahasa arab media adalah perantara atau pengantar pesan dari pengirim kepada penerima pesan. Media merupakan segala sesuatu yang dapat digunakan untuk menyalurkan pesan (message), merangsang pikiran, perasaan, perhatian, dan kemauan siswa sehingga dapat mendorong proses belajar (Aqib, 2002: 58). Media dapat diartikan juga sebagai alat bantu apa saja yang dapat dijadikan sebagai penyalur pesan

Powerpoint adalah sebuah software yang dibuat dan dikembangkan oleh perusahaan Microsoft, dan merupakan salah satu progarm berbasis multimedia. Seperti yang dikemukakan oleh Riyana (2008: 102) sebagai berikut.

Program Microsoft office powerpoint adalah salah satu software yang dirancang khusus untuk mampu menampilkan program multimedia dengan menarik, mudah dalam pembuatan mudah dalam penggunaan dan relatif murah karena tidak membutuhkan bahan baku selain alat untuk menyimpan data (data storage).

\section{METODE}

Penelitian tindakan kelas (PTK) dilaksanakan pada siswa kelas 2 SD Negeri Kalisari pada semester 1 Tahun Pelajaran 2020/2021. Subyek penelitian ini adalah siswa kelas 2 SD Negeri Kalisari semester 1 tahun pelajaran 2020/2021, yang berjumlah 21 siswa, terdiri dari 10 orang siswa laki-laki dan 11 siswa perempuan. Tempat penelitian tindakan kelas di SD Negeri Kalisari Kecamatan Cilongok, Kabupaten Banyumas Provinsi Jawa Tengah. Penelitian tindakan kelas ini menggunakan model spiral yang dikembangkan oleh Kemmis dan Mc. Taggart. Model spiral ini mencakup empat tahap tindakan yaitu perencanaan (planning), tindakan (action), observasi (observation) dan refleksi (reflection).

Tujuan utama penelitian adalah mendapatkan data, teknik pengumpulan data dianggap paling penting dan utama dalam penelitian. Tanpa mengetahui teknik pengumpulan data maka peneliti tidak akan mendapatkan data yang memenuhi standar data yang ditetapkan. Teknik pengumpulan data yang digunakan dalam penelitian ini adalah observasi, tes, dokumentasi.

Instrumen penelitian adalah alat bantu yang dipilih dan digunakan oleh peneliti untuk kegiatan mengumpulkan data agar kegiatannya tersebut lebih sistematis dan lebih mudah. Instrumen yang digunakan dalam penelitian ini adalah lembar obeservasi,tes pemahaman konsep, kamera. 
Analisis yang digunakan dalam penelitian ini adalah teknik deskriptif kuantitatif. Secara rinci, teknik analisis data dalam penelitian ini adalah analisi data lembar observasi, analisi data tes pemahaman konsep.

\section{HASIL DAN PEMBAHASAN}

Pertemuan siklus I dilaksanakan pada hari Senin tanggal 2 November 2020. Pembelajaran berlangsung selama dua jam pelajaran (70 menit), membahas materi bangun datar segilima dan segienam. Semua siswa hadir pada pertemuan ini.

Pada kegiatan inti guru menampilkan slide pada layar serta menjelaskan materi tentang bangun segilima dan segienam. Slide tersebut dibuat menarik dengan memperhatikan prinsip-prinsip pembuatan media powerpoint. Gambar penyajian slide powerpointnya. Siswa terlihat antusias ketika guru menampilkan slide powerpoint. Guru dalam menyampaikan materi disertai dengan tanya jawab. Ketika tanya jawab hanya beberapa siswa saja yang berani bertanya maupun menjawab.

Siswa diminta untuk mengerjakan LKPD yang sudah dikirim di WAG. Kemudian mengirimkan hasil belajarnya kepada guru melalui WAG. Siswa juga diminta mengerjakan evaluasi di google form yang alamat link nya sudah di share di WAG.

Pada kegiatan penutup guru melakukan refleksi mengenai pembelajaran yang baru saja dilakukan. Guru memberi kesempatan kepada siswa untuk bertanya. Guru meminta siswa untuk selalu mematuhi protokol kesehatan dengan memakai masker, cuci tangan pakai sabun, dan makan makanan yang bergizi. Guru memimpin doa dan mengakhiri pembelajaran dengan mengucapkan salam.Pemahaman konsep yang diproleh dari hasil pengerjaan evaluasi siklus I dapat dilihat pada tabel berikut.

Tabel 1. Hasil Pemahaman konsep Peserta didik Siklus I

\begin{tabular}{crrrrr}
\hline Jumlah & \multicolumn{2}{c}{ Ketuntasan } & \multicolumn{2}{c}{ Persentase } & Rata-rata Kelas \\
\cline { 2 - 4 } Siswa & $\mathrm{T}$ & $\mathrm{BT}$ & $\mathrm{T}$ & $\mathrm{BT}$ & \\
\hline 21 & 13 & 8 & $62 \%$ & $38 \%$ & 68 \\
$\mathrm{KKM}=70$ & & & & \\
\hline
\end{tabular}

Dari nilai di atas ketuntasan belajar dari materi yang diajarkan dengan KKM 75 ada 13 peserta didik (62\%) yang tuntas. Sedangkan yang tidak tuntas ada 8 peserta didik (38\%). Pada siklus 1 rata rata kelas yang diperoleh adalah 68. Berdasarkan hasil refleksi pada siklus I ternyata pembelajaran belum berjalan secara maksimal, maka peneliti dengan guru sejawat bermusyawarah merencanakan melakukan perbaikan pembelajaran selanjutnya pada siklus II.

Penelitian siklus II terdiri dari satu kali pertemuan dengan alokasi waktu $2 \times 30$ menit. Dilaksanakan tanggal 2 November 2020, membahas mteri bangun datar segitiga dan lingkaran.

Pada siklus I setelah guru menggunakan media powerpoint peserta didik sudah mengalami peningkatan. Hanya saja masih ada beberapa peserta didik yang asih mengalami kesulitan. Sesuai dengan hasil refleksi siklus I di atas maka diadakan perbaikan tindakan kelas siklus II pada matematika materi bangun datar di kelas II SD Negeri Kalisaei Kec. Cilongok Kab. Banyumas semester 1 tahun pelajaran 2020/2021 dengan menggunakan media powerpoint yang diharapkan dapat meningkatkan pemahaman konsep peserta didik dalam materi bangun datar.

Pada kegiatan inti guru menampilkan slide pada layar yang terdapat gambar dan siswa diminta mendeskripsikan gambar itu. Slide tersebut dibuat menarik dengan memperhatikan prinsip-prinsip pembuatan media powerpoint. Siswa terlihat antusias ketika guru menampilkan slide powerpoint. Guru dalam menyampaikan materi disertai 
dengan tanya jawab guna melengkapi pemahaman setiap point materi yang ada dalam slide pembelajaran yang disediakan oleh guru

Berikut adalah hasil dari siklus II

Tabel 2 Hasil Pemahaman konsep Peserta didik Siklus II

\begin{tabular}{clllll}
\hline Jumlah & \multicolumn{2}{c}{ Ketuntasan } & \multicolumn{2}{c}{ Persentase } & Rata-rata Kelas \\
\cline { 2 - 5 } Siswa & $\mathrm{T}$ & $\mathrm{BT}$ & $\mathrm{T}$ & $\mathrm{BT}$ & \\
\hline 21 & 17 & 4 & $81 \%$ & $19 \%$ & 76 \\
$\mathrm{KKM}=70$ & & & & & \\
\hline
\end{tabular}

Dari nilai di atas ketuntasan belajar dari materi yang diajarkan dengan KKM 75 ada 17 peserta didik (81\%) yang tuntas. Sedangkan yang tidak tuntas ada 4 peserta didik (19\%). Rata rata kelas pada siklus ini adalah 76.

Penilaian hasil pada siklus II menunjukkan guru sudah dapat memberikan motivasi pada peserta didik, guru sudah dapat mengunakan media powerpoint dengan baik, guru sudah dapat mengelola kelas dengan baik dan guru sudah dapat membuat setting kelas dengan baik terutama yang dapat menjadikan peserta didik menjadi aktif.

Begitu juga hasil belajar peserta didik sudah mencapai indikator dengan KKM 75 sebanyak yaitu $75 \%$ karena ketuntasan yang di dapat 17 peserta didik atau $81 \%$, begitu juga keaktifan peserta didik pada rata - rata kelas 76 itu artinya dalam siklus II tindakan sudah baik. Dari penilaian hasil pada siklus II proses pelaksanaan, maka penelitian tindakan kelas ini peneliti hentikan.

Tabel di atas membuktikan dengan beberapa tindakan yang dilakukan guru terutama dalam membimbing peserta didik dan memotivasi untuk aktif maka terjadi peningkatan pemahaman konsep matematika materi bangun datar di kelas II SD Negeri Kalisari pada tingkat ketuntasan yang diinginkan dan dapat meningkatkan siwapeserta didik sebagaimana yang telah direncanakan. Berikut perbandingan hasil siklus I dan siklus II.

Tabel 3. Tabel Perbandungan siklus I dan siklus II

\begin{tabular}{|c|c|c|c|c|c|c|}
\hline \multicolumn{2}{|c|}{ Ketuntasan } & \multicolumn{3}{|c|}{ Persentase } & \multicolumn{2}{|c|}{ Rata-rata Kelas } \\
\hline Siklus I & Siklus II & Siklus I & & & Siklus I & Siklus II \\
\hline $\mathrm{T}$ & $\mathrm{T}$ & BT & $\mathrm{T}$ & BT & & \\
\hline 3 & 7 & 28 & $\begin{array}{c}81 \\
\Lambda=\end{array}$ & 19 & 68 & 76 \\
\hline
\end{tabular}

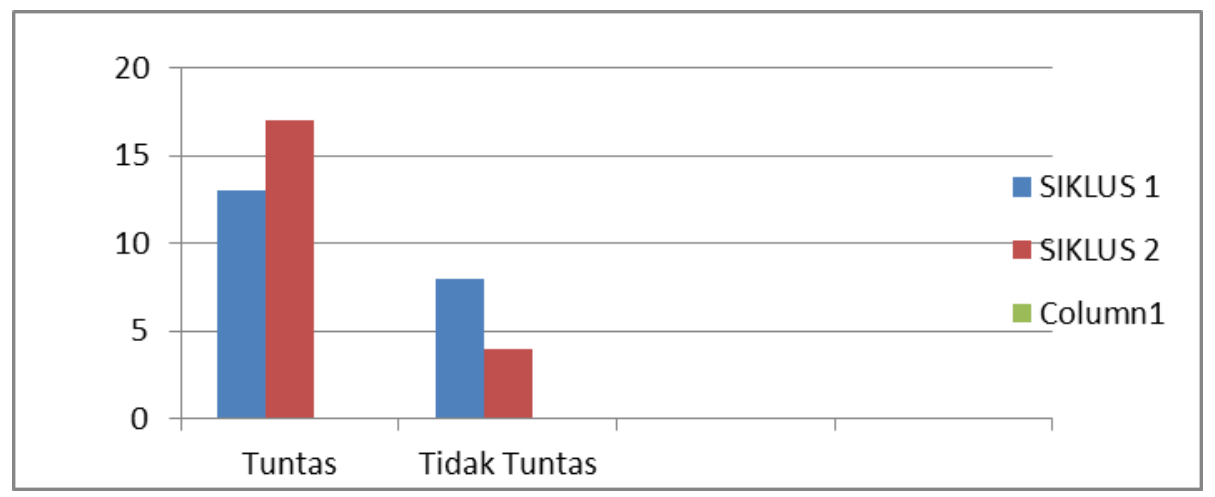

Gambar 1. Diagram Perbandingan Siklus I dan Siklus II 
Berdasarkan tabel pemahaman konsep matematika mengalami peningkatan. Pada siklus I siswa yang tuntas ada 13 orang atau sebesar $62 \%$ dengan rata-rata kelas sebesar 68.Pada siklus II siswa yang tuntas mengalami peningkatan yaitu menjadi 17 orang atau sebesar $81 \%$ dengan rata-rata kelas sebesar 76 . Pada siklus I siswa yang belum tuntas ada 8 orang. Pada siklus II siswa yang belum tuntas berkurang menjadi 4 orang atau sebesar 19\%. Penelitian pada siklus II ini dianggap telah berhasil karena sudah sesuai dengan indikator keberhasilan yang ditetapkan yaitu minimal $75 \%$ dari seluruh siswa yang mengikuti proses pembelajaran telah mencapai taraf KKM yang di tentukan ( $\geq 70)$.

\section{SIMPULAN}

Penggunaan media powerpoint pada Pembelajaran Tema 4 Subtema 2 dapat meningkatkan keaktifan dan pemahaman konsep siswa kelas II SD Negeri Kalisari. Dilihat dari peningkatan pemahaman konsep siswa, ini membuktikan bahwa Pembelajaran tema 4 subtema 2 menggunakan media slide PowerPoint sangat efektif untuk membantu siswa lebih memahami isi dan konsep materi. Dalam penerapan media slide PowerPoint dalam pembelajaran, siswa tampak lebih antusias dalam belajar yang berdampak pada peningkatan pemahaman konsep siswa.

Analisis hasil menunjukkan bahwa nilai rata-rata kelas meningkat. Tindakan pada siklus I nilai rata-rata kelas 68 , dan meningkat pada siklus II menjadi 76 . Peserta didik yang dapat memenuhi ketuntasan belajar juga mengalami peningkatan, pada tindakan siklus I sebanyak 13 siswa atau sama dengan $62 \%$, dan meningkat pada tindakan siklus II menjadi 17 siswa atau sebesar $81 \%$. sehingga dapat disimpulkan bahwa penggunaan media slide PowerPoint dapat meningkatkan Pemahaman konsep Matematika materi bangun datar pada siswa sekolah dasar.

\section{DAFTAR PUSTAKA}

Aqib, Z. (2002). Profesionalisme Guru dalam Pembelajaran. Surabaya: Insan Cendekia.

Ashar Arsyad. (2003). Media Pembelajaran. Jakarta : PT. Raja Grafindo Persada. (2006). Media Pembelajaran. Jakarta : PT. Raja Grafindo Persada. (2009). Media Pembelajaran. Jakarta : PT. Raja Grafindo Persada.

Depdiknas. (2000). Kamus Besar Bahasa Indonesia Edisi Ketiga. Jakarta: Balai Pustaka

Depdiknas. (2003). Undang-undang Republik Indonesia Nomor 20 Tahun 2003 tentang Sistem Pendidikan Nasional. Jakarta: CV. Eka Jaya.

Sadiman, dkk. (2009). Media Pendidikan: Pengertian, Pengembangan, dan pemanfaatannya. Jakarta: Rajawali Press.

Sudarwan Danim. (1995). Transformasi Sumber Daya Manusia. Jakarta: Bumi Aksara. Suharsimi Arikunto. (2006). Prosedur Penelitian Suatu Pendekatan Praktik. Jakarta: Rineka Cipta.

Suroso. (2009). Penelitian Tindakan Kelas. Yogyakarta: Pararaton. 